bined in $195 \mathrm{I}$ as the Pure and Applied Sciences Section to bring ACRL to its section status as of 1956.

\section{Things Begin to Happen}

The effect of autonomous status for the college librarians within ALA was immediate and electric. Interest in the new association zoomed, convention programs multiplied and took on additional zest and stature. Membership increased rapidly over the few hundreds of the College and Reference Section. The College Library Advisory Board, which had done yeoman's service during the thirties, felt that it could now safely recommend itself out of existence. Most important of all, College \& Research Libraries was born.

It would be difficult to over-assess the vitalizing and stimulating effect of College \& Research Libraries on college librarianship and on the growth and development of ACRL. "The time has long passed," said Editor Kuhlman, in his introductory statement, "when a single general library organization and its official journal were adequate to meet the professional needs of college, university, and reference librarians." Noting Abraham Flexner's emphasis, in his analysis of a profession, on a medium of communication, Mr. Kuhlman said, "It has been the absence of a professional journal devoted specifically to the interests of college, university and reference libraries which no doubt accounts, to a large extent, for the lack of a definitive literature dealing with these institutions." ...

While College \& Research Libraries was off and running immediately, not so the organization for which it was the official organ.
The ALA could not easily change its spots. It took time, in spite of its reorganized machinery and structure, for it and its headquarters staff to reorient thinking, activities and financing to the new order of things. Funds for the longawaited and long-promised executive secretary at headquarters were still not available. Rumblings of discontent among college librarians grew correspondingly. There was much talk and some planning to take ACRL out of ALA entirely and establish its headquarters on some college campus. Officers of the early 1940 's were under considerable pressure to take this drastic step.

\section{A Headquarters Staff at Last}

It was not until ALA came to the hard decision to draw on principal to finance a headquarters staff for ACRL that the council approval of 1932 was finally consummated. This happened in April of 1947. . . .

.. ACRL has grown rapidly in prestige and accomplishments. It has achieved a somewhat uneasy but reasonably effective division of membership dues with its parent ALA so that it must no longer, in effect, eat seed corn. It has also become soundly integrated with its sections and better integrated with the ALA. Its membership is now over 5,400 , it is in a healthy financial condition, its official journal ranks with the best of its class in whatever field, it is issuing other publications of stature, its sections are thriving, and it is amply calling forth intelligent and able leadership from its ranks. It took a long time, but one hundred years after the beginnings, college, university, and reference librarians have a strong, virile, and effective organization equal to the difficulties, opportunities and challenges ahead.

\title{
From the ACRL President
}

Since Midwinter:

1. ALA Reorganization. The ACRL Executive Committee has had an opportunity to see a preliminary copy of the latest ACONDA findings which are to be presented to membership at Dallas. In it there is a proposal for a further study of reorganization, but suggesting either the triad or the federation concept. ACRL still supports the federation proposal. It also supports the new ACONDA proposal for further study and suggests that ACRL recommend that no interim changes be made in the structure or organization of individual aspects of ALA until a final decision on the reorganization proposal is made.

In my earlier memo to you in the News, I indicated that we would keep ACRL member- ship informed of our own study on the matter of federation. Following the Midwinter Meetings in Los Angeles, we set up three task forces to analyze and prepare recommendations, assuming federation, with respect to three areas of concern to us. These are listed below with the names of ACRL members serving on them who, I am sure, would be happy to receive any suggestions from the membership.

Structure: Joanne Harrar, University of Georgia; William Pullen, Georgia State College; Hal Stone, Los Angeles City College.

Goals: Louis Jacob, University of Pennsylvania; Marc Gittelsohn, University of California, Berkeley; Darrell Lemke, Consortium of Universities, Washington.

Finances: Mark Gormley, Wayne State 
University; James Humphry, H. W. Wilson Co., Bronx, N.Y.

We are planning an all-day meeting of these task forces and the Executive Committee in Dallas on Sunday, June 20, at which we hope to produce final recommendations which will be presented to the ACRL Board of Directors and then for discussion by ACRL membership.

2. Internship Committee. The Board of Directors approved, upon the recommendation of the Planning Committee, the establishment of a committee to develop a program for providing further training and assistance in the development of professional skills for black librarians and librarians from other minority groups. The Committee consists of Mrs. Virginia Lacy Jones, Katharine Stokes, David Weber, Mrs. Annette Phinazee, and Mrs. Phyllis Cartwright.

3. Legislation. As many of you know, the Higher Education Act of 1965 runs out at the end of June. In addition, the availability of funds has been curtailed and the guidelines for their distribution redefined. The ALA Washington Office has been concerned with recommendations to congressmen regarding the extension of the Act, the increase in appropriations, and the guidelines for allocation of funds. To assist the Washington Office in its work, it has been given a list of college librarians who could, when called on for quick action, contact their own representatives and senators. Each ACRL librarian should also assume individual responsibility for similar action.

4. Dallas. The ACRL formal program time is being reserved for reports on various ACRL activities, with specific discussion directed to the work of the Academic Status Committee and discussion of federation proposals.-Anne C. Edmonds, President, ACRL.

\section{ACRL Board of Directors}

\section{MIDWINTER MEETING LOS ANGELES, 1971}

Bhief of Minutes

Monday, January 18, $1971-8: 30$ p.m.

Present: President, Anne C. Edmonds; VicePresident and President-Elect, Joseph H. Reason; Past President, Philip J. McNiff; Directors-at-Large, Mark M. Gormley, Norman E. Tanis, David C. Weber; Directors on ALA Council, Page Ackerman, Andrew J. Eaton, Warren J. Haas, James F. Holly, Robert K. Johnson, Sarah D. Jones, James O. Wallace; Chairmen of Sections, Carl H. Sachtleben, Mrs. Joleen Bock, Julius P. Barclay, Eleanor Buist, David W. Heron; Chairmen and Chairmen-Elect of Sections, Carl R. Cox, Hal C. Stone, Lee Ash, Wolfgang M. Freitag; Executive Secretary, J. Donald Thomas; Professional Assistant, Jordan M. Scepanski; Administrative Assistant, Elaine Swanson.

Absent: Robert H. Blackburn, Herbert A. Cahoon, Ralph H. Hopp, Andrew Horn.

Visitors: Warren Boes, Brendan Connolly, D. Davisson, Stuart Forth, Beverly Johnson, Arthur Plotnik, Eldred Smith, W. B. Walker.

President Anne C. Edmonds presided.

The meeting was called to order, and the minutes of the Detroit meetings were approved as published. Miss Edmonds then asked Mr. Thomas to report on the mail votes of the ACRL Board of Directors during the fall. Mr. Thomas noted some concern about mail bal- lots and asked for opinions on this procedure. Mr. Holly supported the procedure as a means of expediting Board business and thus reducing time requirements at regular meetings. Mr. Weber asked who approved mail ballots. Mr. Thomas answered that the first set of ballots was sent upon the decision of the executive committee, while the second was sent out at the request of the Committee on Academic Status. Mr. Weber expressed the opinion that the officers should always determine what should be brought to a mail vote. He further stated there should be a requirement for a statement by an individual in opposition to a particular resolution. Statistical studies would seem to indicate that resolutions sent without such opposition statements are always supported he said, citing as examples the nearly unanimous approval of the various resolutions. Mr. Weber then Moved that a majority of the Executive Committee concur in submitting a mail ballot to the Board. and, when possible, a member of the association be found to provide a written statement of opposition. Mr. Tanis SECONDED.

Mr. Eaton then asked if, instead of merely an opposing viewpoint, a statement of the problem with advantages and disadvantages of the resolution set forth might not be better. Mr. Weber replied that he assumed a committee wishing to submit an issue to a mail ballot would want to support it; that what would be lacking is a contrasting view. Mr. Tanis did not believe the officers would necessarily be in favor of an issue submitted for a mail vote. $\mathrm{He}$ 